\title{
Wildfire history and fire ecology of the Swiss National Park (Central Alps): new evidence from charcoal, pollen and plant macrofossils
}

\author{
Markus Stähli, ${ }^{1}$ Walter Finsinger, ${ }^{2}$ Willy Tinner $^{3}$ and \\ Britta Allgöwer ${ }^{1 *}$
}

\author{
${ }^{1}$ Department of Geography, University of Zurich, Winterthurerstrasse 190, \\ CH-8057 Zurich, Switzerland; ${ }^{2}$ Institute of Environmental Biology, Paleoecology, \\ Laboratory of Paleobotany and Palynology, 3584 CD Utrecht, the Netherlands; \\ ${ }^{3}$ Institute of Plant Sciences, Section Palaeoecology, University of Bern, \\ Altenbergrain 21, CH-3013 Bern, Switzerland)
}

Received 15 February 2005; revised manuscript accepted 6 February 2006

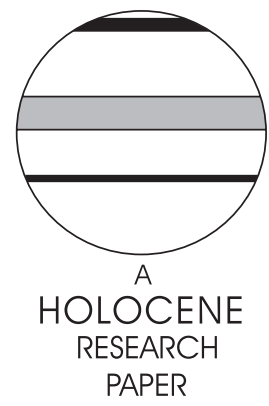

\begin{abstract}
Microscopic $(>10 \mu \mathrm{m})$ and macroscopic $(>200 \mu \mathrm{m})$ charcoal particles were analysed in sediments from two mires in subalpine coniferous forests at c. $1800 \mathrm{~m}$ a.s.l. in southeastern Switzerland. Pollen and plant macrofossils suggest that since 6000 BC, Pinus mugo ssp. uncinata (DC) Domin ('upright mountain pine') has mostly been the dominant tree species at one of the study sites (Il Fuorn). In contrast, forests dominated by Picea abies (Norway spruce) have formed the vegetation since $c .4000 \mathrm{BC}$ around the mire 'Fuldera-Palü Lunga'. Mean fire-return intervals (MFI) varied from 250 to $>600$ years, depending on forest type, climate and land use. In mountain-pine forests (Il Fuorn), local fires occurred approximately every 250 years, even before the region was agriculturally used (ie, before 3600 BC). About 2000 years ago, intensified human impact as documented by the pollen record resulted in increased fire activity at Fuldera. Post-fire vegetation dynamics suggest that the mountain-pine stands at Il Fuorn had a moderate fire regime with a mix of surface and crown fires. In alpine ecosystems, the impact of fire is generally overshadowed by other disturbance factors such as windthrow, landslides, fungal decay and by climate changes or human land use. Nevertheless, our results show for the first time that natural wildfires exerted a major control on the subalpine coniferous forest ecosystems of the Swiss National Park and its neighbouring areas, eg, by contributing to maintain Pinus mugo ssp. uncinata forests throughout the mid and late Holocene.
\end{abstract}

Key words: Charcoal analysis, macroscopic charcoal, fire history, fire intervals, central Alps, Pinus mugo ssp. uncinata, mountain pine, Holocene.

\section{Introduction}

Although park legislation (Nationalparkgesetz, 1980) protects all natural processes within the borders of the Swiss National Park (SNP), all fires are suppressed at present, regardless of whether they are natural or human induced. Knowledge of fire and its long-term role in this landscape is lacking. In Central Europe, wildfire still receives very little attention in both nature conservation and management, and its potential managerial benefits are generally disregarded, eg, the fact that lowintensity surface fires prevent severe crown fires by burning

*Author for correspondence (e-mail: britta@geo.unizh.ch) dead wood and create disturbed areas where pioneer species can sprout. In this regard, knowledge of fire history can help the design of a future management plan for the SNP that allows for certain naturally caused fires (Allgöwer et al., 2003).

The SNP is located in one of the driest regions of the Alps, the Engadine Valley (Canton of Grisons). Only $900 \mathrm{~mm}$ of precipitation per year are measured at the meteorological station of Buffalora (1970 m a.s.l.) in the Fuorn Valley by the meteorological service MeteoSwiss. The climatic setting, together with the extensive mountain-pine forests (Pinus mugo ssp. uncinata (DC) Domin), on the SNP area is one of the most wildfires-susceptible regions in Switzerland. This was shown by the elaboration of area-specific fuel models (Allgöwer et al., 
1998), by statistical evaluation of twentieth-century fires (Langhart et al., 1998) and by fuel investigations (Allgöwer and Gleason, 2001). In fact, both within and close to the SNP some severe, stand-replacing forest fires have even occurred in the past century due both to lightning and human negligence (eg, 1951 at Il Fuorn, 1964 at Ova Spin or 1983 above Müstair).

Holocene fire-history studies have contributed to the understanding of fire regimes and ecosystem interrelations in both North America (eg, Patterson et al., 1987; Clark, 1988b; Mohr et al., 2000) and Northern Europe (eg, Bradshaw et al., 1997; Pitkänen et al., 2002). However, in our study area we lack a detailed knowledge of fire history. Charcoal records from the Alps have been examined in a few previous studies, but these projects were either located outside the Central Alps (Berli et al., 1994; Carcaillet, 1998; Tinner et al., 1999) or did not focus on fire-interval reconstruction (Wick and Tinner, 1997; Gobet et al., 2003).

So far the vegetation history of the SNP area has been based on pollen analysis alone (Welten, 1982; Zoller et al., 1996). This has restricted the interpretation of the palaeovegetational data. In contrast, the macrofossil data from this study enable us first to obtain information on the local vegetation history at the coring sites (Birks and Birks, 2000) and second to distinguish the remains of Pinus mugo ssp. uncinata (mountain pine) and Pinus sylvestris (Scots pine).

Our main aim was to estimate natural fire-return intervals in the SNP area. Further, this paper deals with the following questions. (1) How is fire activity connected with human activities, climate and the existing forest type? (2) Which species profit from fires, and which are inhibited? (3) What vegetation can be considered as natural on the basis of the palaeovegetational records in the central SNP area?

Taxonomic nomenclature in this paper follows Lauber and Wagner (1996), who propose 'Pinus mugo ssp. uncinata (DC) Domin' ('upright mountain pine' and the synonyms $P$. montana Miller ssp. arborea, P. montana grex arborea (Zoller, 1995) and $P$. uncinata Miller ex Mirbel).

\section{Material and methods}

\section{The coring sites}

Two small mires in southeastern Switzerland were cored (Figure 1), both of which cover an area of approximately $10 \mathrm{~m} \times 10 \mathrm{~m}$. Il Fuorn (1805 m a.s.l.) lies in the Fuorn Valley and is referred to as the only boggy location in the whole park area (Welten, 1982). It is surrounded by the largest Pinus mugo ssp. uncinata stands of the Alps, which are intermingled with few Pinus cembra (Swiss stone pine) and Larix decidua (European larch) (Zoller, 1995). The second mire (FulderaPalü Lunga, $1822 \mathrm{~m}$ a.s.1.) is situated on the southern slope of the Müstair Valley. This slope is covered by Picea abies (Norway spruce) forests with sparse Larix decidua, Pinus mugo ssp. uncinata and Pinus cembra (Zoller, 1995).

\section{Coring and sediments}

The cores were taken in September 2002 with a Steif modification of the Livingstone piston corer (Merkt and Streif, 1970). At Il Fuorn, a core of $255 \mathrm{~cm}$ length was taken. The sediment consisted of peat in the upper part of the core $(<55 \mathrm{~cm})$ and peaty gyttja beneath. However, the organic sediment is interrupted by gravel layers at 68 to $88 \mathrm{~cm}, 110$ to $145 \mathrm{~cm}$ and below $205 \mathrm{~cm}$ depth. The core from Fuldera was $215 \mathrm{~cm}$ long and comprised a continuous peat body that extended from the top to gravel at $150 \mathrm{~cm}$ depth. To investigate fire and vegetation history, only samples of the organic sediment layers (peat and gyttia) were analysed.

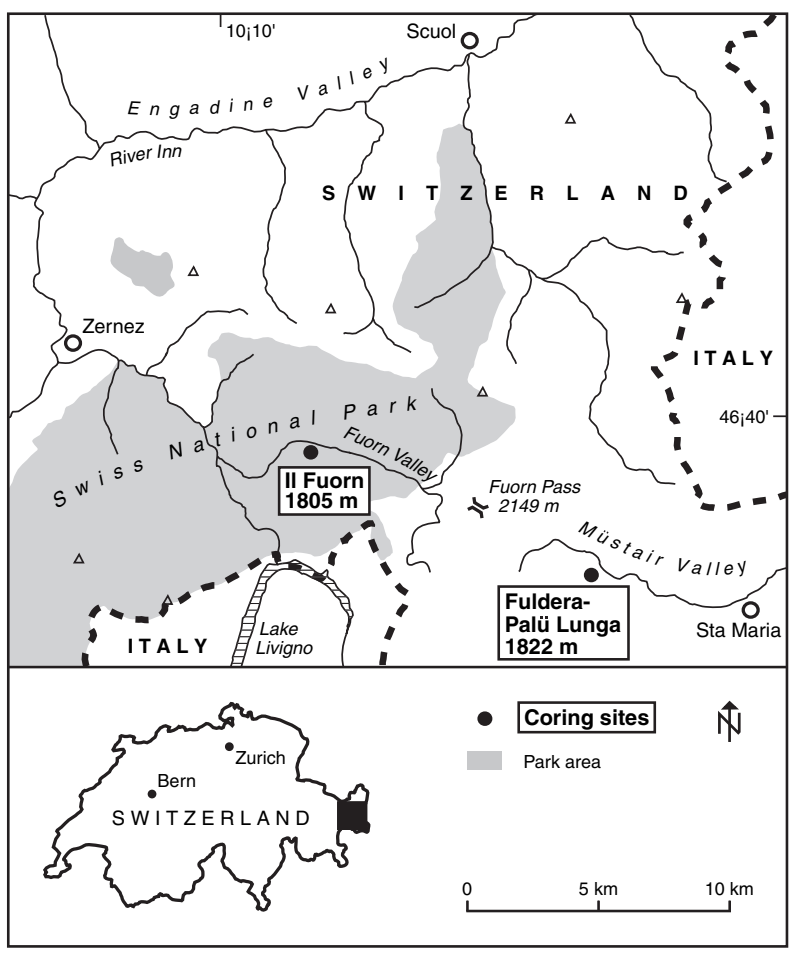

Figure 1 Map of the study area in southeastern Switzerland

\section{Pollen}

Sediment cubes of $1 \mathrm{~cm}^{3}$ were retrieved from every sixth centimetre of the core sections containing organic sediment and from every centimetre between 180 and $190 \mathrm{~cm}$ depth from Il Fuorn. Four extra samples from Fuldera (82, 86, 112 and $116 \mathrm{~cm}$ depth) were also taken. The samples were treated physically by sieving (at $250 \mu \mathrm{m}$ ) and decanting, as well as chemically ( $\mathrm{HCl}, \mathrm{KOH}, \mathrm{HF}$, Acetolysis), following standard procedures of Bennett and Willis (2001). The residue was stained with fuchsin, mounted in glycerin jelly and analysed at $\times 400$ magnification. Exotic markers were added in order to calculate charcoal, pollen and extrafossil concentration according to Stockmarr (1971). Pollen and spores were identified with the key of Moore et al. (1991) and the atlas of Reille (1992, 1995). Numerical zonation was performed with the ZONE program using the method of optimal partitioning (Birks and Gordon, 1985). The determination of statistically significant zone boundaries is based on the 'broken stick model' (Bennett, 1996).

\section{Plant macrofossils}

To allow for the analysis of both plant macrofossil and macroscopic charcoal, the sediment was cut into 1 -cm-thick slices $\left(10 \mathrm{~cm}^{3}\right)$ and washed through a sieve with mesh of $200 \mu \mathrm{m}$. Botanical remains were identified with the aid of reference material from the Institute of Plant Sciences and the Botanical Garden at the University of Bern and keys by Godet (1983, 1998), Schoch et al. (1988), Lévesque et al. (1988), Tobolski (1992), and Latalowa (1999). Cross-sections of individual Pinus needles were prepared in order to distinguish Pinus mugo from Pinus sylvestris. According to Zoller (1981), the height/width ratio of epidermis cells in the majority of cases is $>2$ for P. mugo, but only between 1 and 2 for P. sylvestris.

\section{Microscopic charcoal}

Charcoal particles longer than $10 \mu \mathrm{m}$ were counted in all pollen slides with a light microscope at $400 \times$ magnification. Only black, completely opaque and sharp-edged fragments were classified as charcoal (Clark, 1988b; Tinner et al., 1998). 
Table 1 AMS-radiocarbon dates from Il Fuorn (Il) and Fuldera (Fu) measured by Ångström Laboratories, Uppsala, Sweden

\begin{tabular}{|c|c|c|c|c|}
\hline Sample depth $(\mathrm{cm})$ & Lab code & $\begin{array}{l}\text { Conventional }{ }^{14} \mathrm{C} \text { age } \\
\text { (years BP uncal.) }\end{array}$ & $\begin{array}{l}\text { Calibrated age } \\
\text { (calendar year) }\end{array}$ & 2 -sigma range $(95 \%)$ \\
\hline 40 (Il) & Ua-20596 & $2380 \pm 45$ & 404 вС & $758-385$ вс \\
\hline 89 (Il) & Ua-20597 & $3910 \pm 50$ & 2429 вС & $2559-2205$ вС \\
\hline 104 (II) & Ua-20598 & $4240 \pm 50$ & 2882 вС & $2918-2676$ вс \\
\hline 151 (II) & Ua-21742 & $5305 \pm 70$ & 4139 вС & $4330-3969$ вС \\
\hline 173 (Il) & Ua-20599 & $5875 \pm 100$ & $4748 \mathrm{BC}$ & $4957-4464$ вС \\
\hline 198 (Il) & Ua-20600 & $7045 \pm 70$ & 5946 вС & $6051-5739$ вС \\
\hline $48(\mathrm{Fu})$ & Ua-21740 & $1035 \pm 35$ & AD 995 & AD $897-1025$ \\
\hline $106(\mathrm{Fu})$ & $\mathrm{Ua}-21741$ & $4150 \pm 40$ & 2767 вС & $2881-2579$ вС \\
\hline $147(\mathrm{Fu})$ & Ua-20601 & $5090 \pm 50$ & 3942 вС & $3980-3770$ вС \\
\hline
\end{tabular}

The counting of each sample involved a minimum of 30 charcoal particles and 100 Lycopodium spores or vice versa.

\section{Macroscopic charcoal}

Along with the plant macrofossils, charcoal particles larger than $200 \mu \mathrm{m}$ in diameter were counted with a binocular microscope at $6 \times$ to $50 \times$ magnification. The surface area of each particle was determined with the ruler of the microscope objective. Charcoal selection was restricted to completely black, glittery fragments that would collapse if touched with tweezers. Further, particles with a length/width ratio larger than 3 were excluded from the analysis as they are more likely to originate from burned grass than from burned wood (Umbanhowar and McGrath, 1998).

Although single pieces of charcoal can be transported over long distances $(>1 \mathrm{~km})$, particles longer than $200 \mu \mathrm{m}$ are largely deposited in the vicinity of a fire. Therefore macroscopic charcoal provides a record of local fires, whereas regional fire history can be derived from microscopic particles (Clark, 1988a; Whitlock and Larsen, 2001; Carcaillet et al., 2001). To allow for fire-event dating, the macroscopic record was counted in contiguous samples.
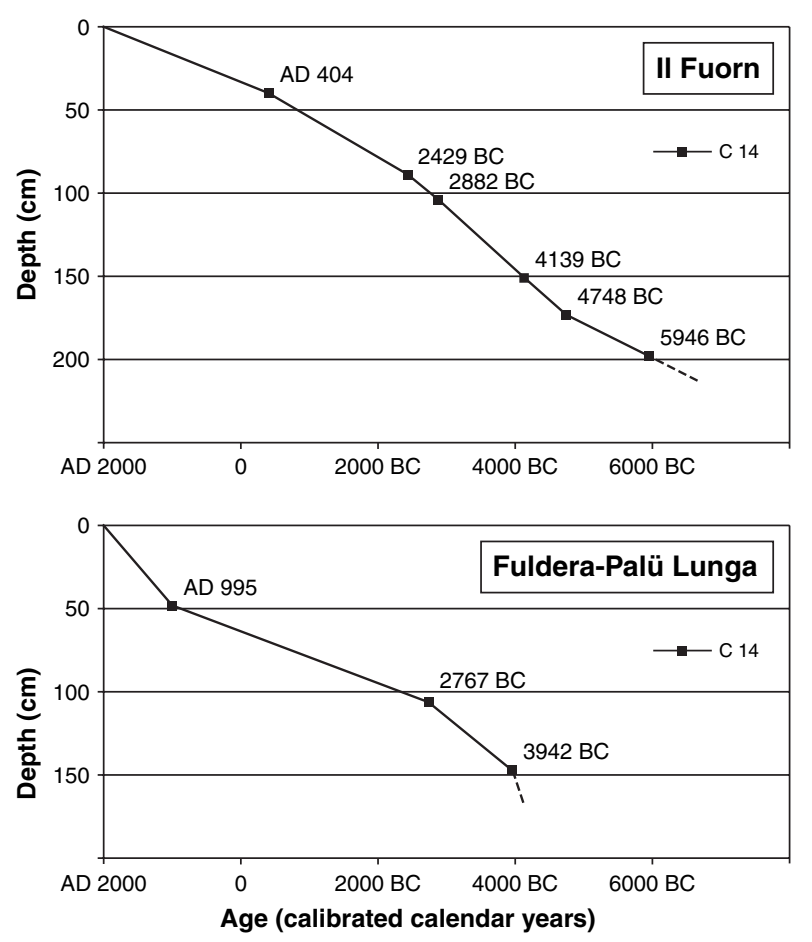

Figure 2 Depth-age models of the sediments from Il Fuorn and Fuldera

\section{Estimation of fire-return intervals}

According to Whitlock and Larsen (2001), we drew a distinction between primary charcoal, which is deposited during or shortly after a local fire, and secondary charcoal, which originates from distant fires or from sediment-mixing. In order to eliminate the effect of secondary charcoal, the macroscopic charcoal influx $\left(\mathrm{mm}^{2} / \mathrm{m}^{2}\right.$ per yr) was smoothed with a locally weighted regression model (Lowess; span $=10 \%$; see Tinner et al., 1998). The smoothed values were then subtracted from the raw figures to isolate positive residual peaks, which are assumed to represent local fire events (Long et al., 1998; Lynch et al., 2004). Fire-return intervals are the time between two adjacent peaks. However, only peaks with a charcoal concentration of $>3 \mathrm{~mm}^{2} / 10 \mathrm{~cm}^{3}$ were identified as fire events regardless of their residual values.

Mean fire-return intervals (MFI) usually result from averaging individual intervals. Slightly different from the common definition (eg, Whitlock and Larsen, 2001), MFI were here calculated as the number of years covered by a sediment section divided by the number of fire events that occurred during the respective time span. In this manner, fire-free periods at the beginning or at the end of every sediment section are also taken into account in the analysis.

\section{Chronology}

Core chronologies for Il Fuorn and Fuldera were based on six and three AMS radiocarbon dates, respectively (Table 1). Wooden twigs with remaining bark fragments were selected for dating because bark remains generally do not persist long before being sedimented (Oswald et al., 2005). Radiocarbon dates were calibrated to calendar years (BC/AD) using Calib 4.3 (Stuiver et al., 1998). If several dates resulted from the calibration, the average value was chosen for the depth-age models. Linear interpolation or extrapolation was used to assign ages both between the dated layers and under the lowest dated depths. The depth-age curves turned out to decrease steadily (Figure 2). Within the gravel layers of the Il Fuorn core, the dates remain uncertain, as such gravel is not likely to have been deposited continuously. However, this limitation is without consequence, as the results of this study are based only on sediment sections with organic matter.

\section{Results and interpretation}

\section{Vegetation history of Il Fuorn}

The pollen records suggest that Pinus was usually the dominant tree in the forests around Il Fuorn (Figure 3). Although we did not differentiate pollen of Pinus mugo and Pinus sylvestris, we assume that the vast majority of Pinus pollen ( $P$. mugo-type) in the core from Il Fuorn originates from P. mugo because (1) all Pinus needles selected for cross-sections 


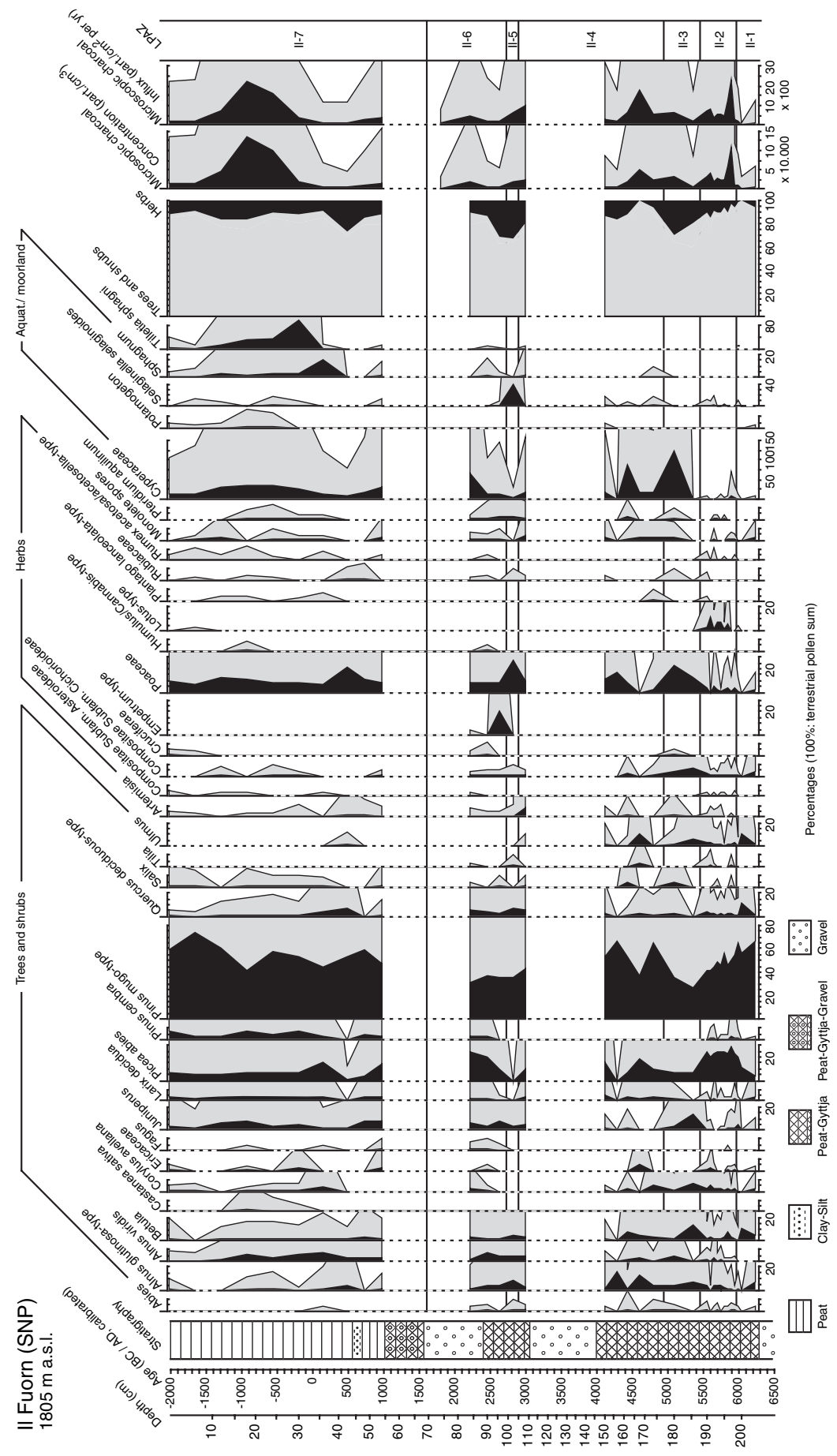

Figure 3 Diagram showing pollen percentages of selected taxa as well as microscopic charcoal concentration and influx for Il Fuorn. Analysis: W. Finsinger (pollen), M. Stähli (charcoal)

were identified as P. mugo, (2) because P. mugo ssp. uncinata is today dominant in the forests around Il Fuorn, and (3) in southeastern Switzerland P. mugo is known to grow preferentially on calcareous bedrock (Zoller, 1995), which can be found in the surroundings of Il Fuorn (dolomite). Mountain-pine forests were intermingled with varying amounts of Picea abies, Larix decidua and Pinus cembra. However, Picea abiesdominated forests temporarily replaced them.

The pollen stratigraphy was split up into seven local pollen assemblage zones (LPAZ) that showed statistically significant differences. In the 34 samples, a total of 66 pollen and spore types from terrestrial plants, five pollen and spore types from aquatic and moorland plants and three ferns were identified.

LPAZ Il-1 (204-198.5 cm, 6230-5970 вC) reveals a Pinus mugo-dominated community, as Pinus mugo-type pollen ac- counts for more than $60 \%$ of the terrestrial pollen sum. Thus, Pinus mugo was widespread, even though its pollen is usually over-represented in pollen assemblages (Lang, 1994; Burga and Perret, 1998). Mountain-pine stands were mixed with Picea abies (Picea pollen increases form 3\% to $20 \%$ in the course of this zone) and Larix decidua (Larix pollen reaches 4\%). Pinus mugo-type periderm fragments (P. mugo/P. sylvestris) confirm the existence of pine-dominated forests (Figure 4).

During LPAZ Il-2 (198.5-188 cm, 5970-5470 BC), Picea abies pollen constantly exceeds $20 \%$, whereas Pinus mugo-type pollen declines from over $50 \%$ to $40 \%$. The macrofossil record shows numerous periderm fragments of Picea abies or Larix decidua. According to this, Norway spruce stands temporarily replaced the former mountain-pine stands. We suppose that warmer summer temperatures facilitated the spread of Picea 


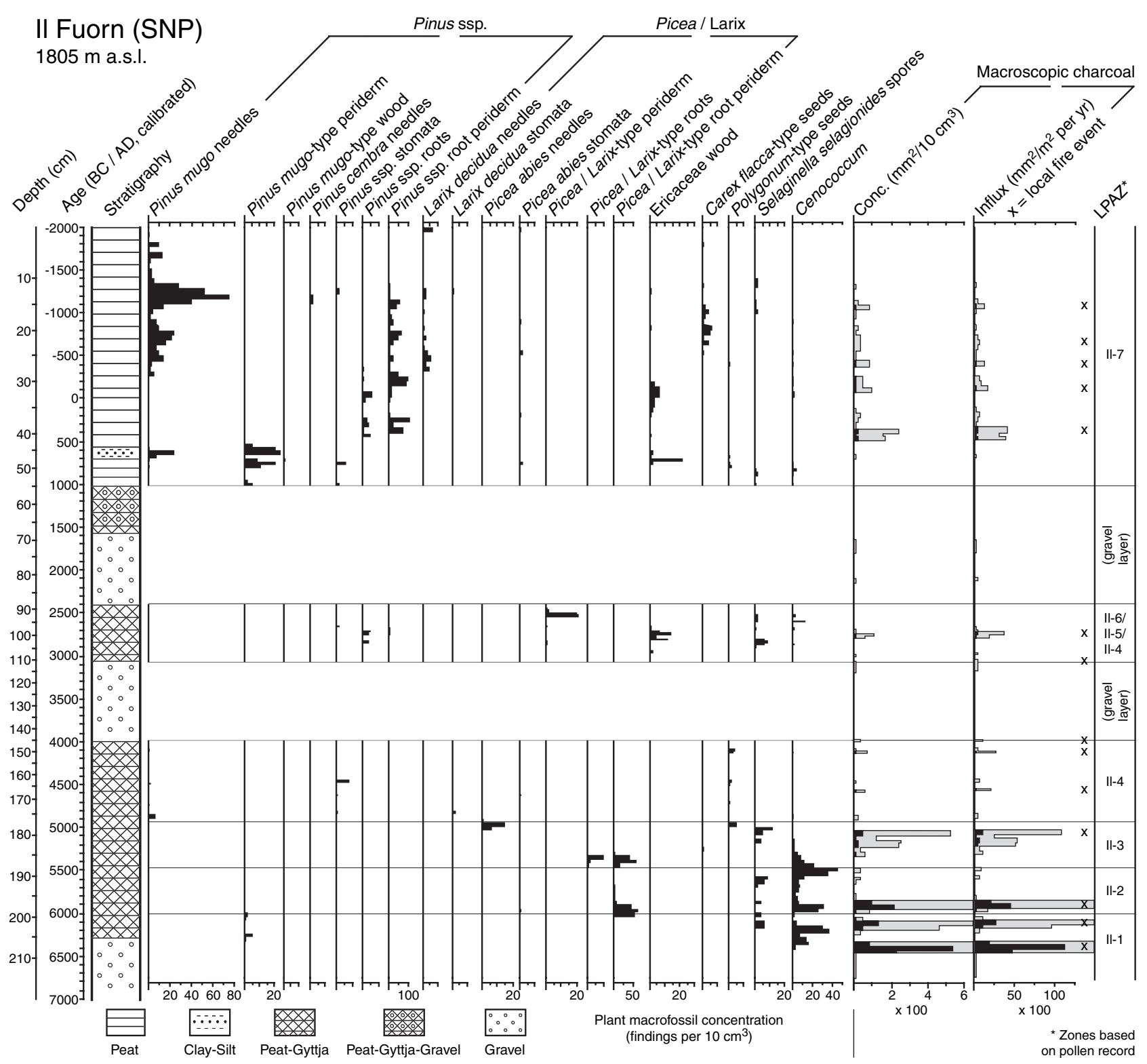

Figure 4 Diagram showing selected plant macrofossil concentrations as well as macroscopic charcoal concentration and influx for Il Fuorn. Analysis: M. Stähli

abies, which today grows at slightly lower altitudes (Welten, 1982). In fact, the later part of LPAZ Il-2 is situated between two 'Central European cold-humid phases' identified by Haas et al. (1998) (CE-3: 6420-5740 BC, CE-4: 5575-5130 вC).

LPAZ Il-3 (188-177 cm, 5470-4940 BC) is characterized by high percentages of non-arboreal pollen, especially in the sample from $180 \mathrm{~cm}$ depth (5080 BC), in which Poaceae and Cyperaceae pollen reach maxima of $22 \%$ and $122 \%$, respectively. This indicates that the forests thinned out significantly, in response to either the cold-humid phase CE-4 (5575-5130 $\mathrm{BC}$ ) or the fire event that dates from 5100-5000 BC (Figure 5).

Tree and shrub pollen no longer fall below $80 \%$ during LPAZ Il-4 (177-152/108-105 cm, 4940-4170/2990-2910 вС). The coniferous forests thus recovered from the preceding collapse. However, the tree composition within the pollen zone seems non-uniform. Pinus mugo-type pollen is dominant and constantly exceeds $50 \%$ with the exception of the sample from $168 \mathrm{~cm}$ depth (Pinus mugo-type: 36\%). Larix decidua pollen remains stable between $3 \%$ and $4 \%$, whereas Picea abies pollen varies between $7 \%$ and $18 \%$. In the macrofossil sample at $177 \mathrm{~cm}$ depth, 15 Picea abies needles were found. Mixed mountain-pine stands covered the Fuorn Valley, but Picea abies managed to invade temporarily. As Larix decidua pollen is usually strongly under-represented (Lang, 1994; Burga and Perret, 1998), its low abundance indicates that it has been widespread form c. $4800 \mathrm{BC}$ until the present time.

LPAZ Il-5 (105-99 cm, 2910-2730 BC) consists of a single pollen sample $(102 \mathrm{~cm})$, which shows high percentages of nonarboreal pollen (Poaceae: $27 \%$ ) and spores (43\% of Selaginella selaginoides microspores in the pollen slide as well as several macrospores). Similar to LPAZ Il-3, an opening is implied in the forest canopy, affecting Picea abies in particular. It remains uncertain whether this breakdown reflects a reaction to the cold-humid phase CE-6 (3360-3020 BC) or whether it was caused by an individual disturbance event, such as windthrow, a landslide or fungal decay. However, the charcoal records do not suggest forest clearance by fire.

During LPAZ Il-6 (99-84 cm, 2730-2220 BC), tree and shrub pollen again increase to over $90 \%$. This is with the exception of the lowest sample $(96 \mathrm{~cm})$, which resembles the previous pollen zone (LPAZ Il-5) despite its position in the statistical zonation. Then, after c. 2600 BC, the forest canopy recovered. Picea abies pollen percentages range from 20\% to $25 \%$ and Pinus mugo-type from $30 \%$ to $35 \%$. Thus we can refer 

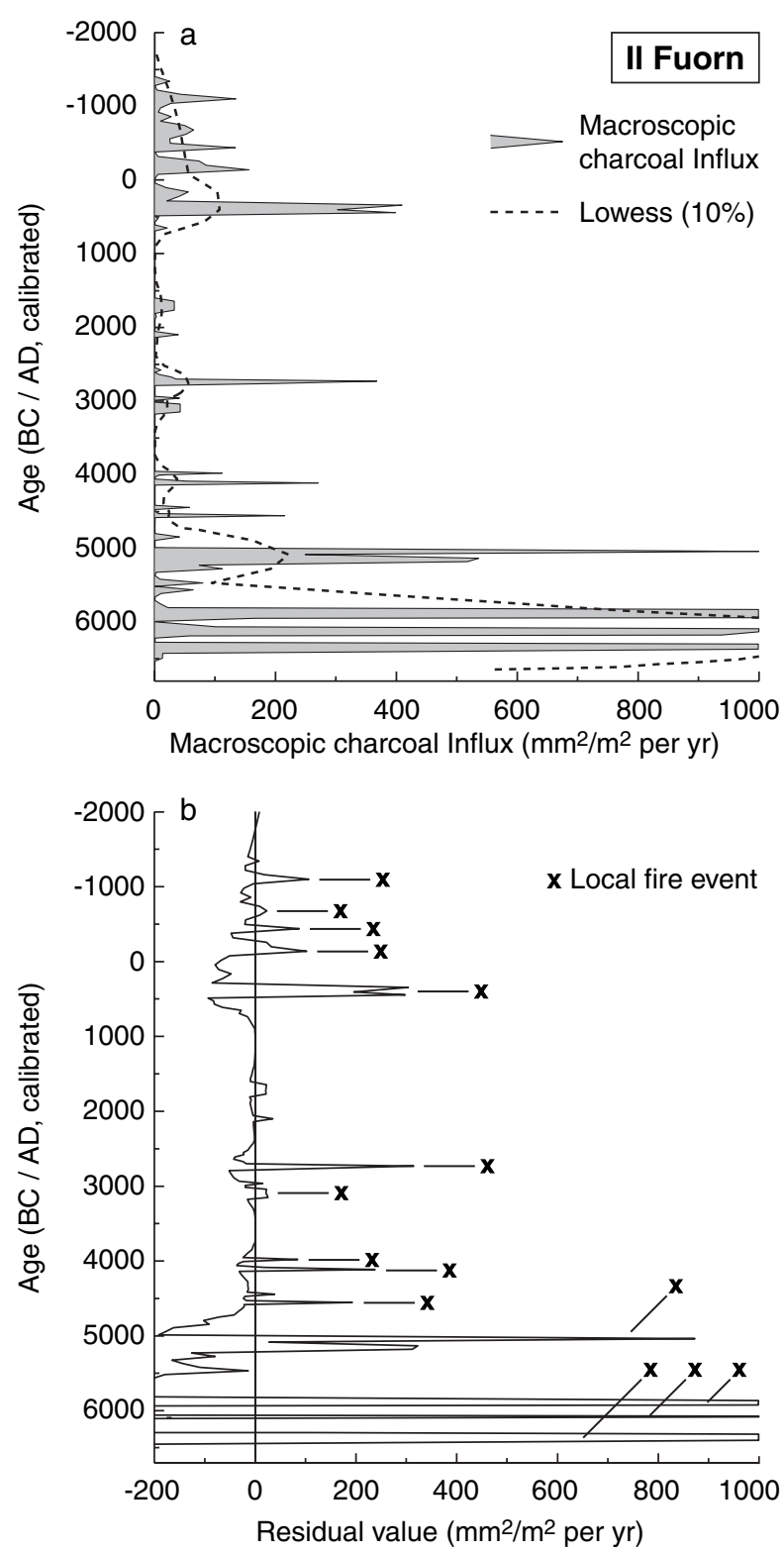

Figure 5 (a) Smoothed curve of macroscopic charcoal influx for Il Fuorn (Lowess; span $=10 \%$ ). (b) Residual peaks (difference between influx and smoothed values) that were interpreted as local fire events

to the regional vegetation as mixed spruce-mountain-pine stands. Pinus cembra pollen reaches $3 \%$ to $6 \%$ from c. 2500 вC to the present. As percentages of $5 \%$ can already stand for local presence of Pinus cembra (Burga and Perret, 1998), a considerable number of Pinus cembra have been intermingled with Picea abies and Pinus mugo ssp. uncinata since then.

In LPAZ Il-7 (54-0 cm, $980 \mathrm{BC}-$ present), tree and shrub pollen again exceed $80 \%$. Pinus mugo-type pollen ranges from $45 \%$ to $70 \%$, whereas Picea abies pollen was less frequently found than in older sediment sections. The macrofossil record, which here shows numerous needles, confirms the dominance of Pinus mugo ssp. uncinata. According to the pollen record, the re-established mountain-pine forests have been mixed with Picea abies, Larix decidua and Pinus cembra with a closed canopy until the present time. Only at around 480 BC $(42 \mathrm{~cm}$ depth), do they appear to have thinned out temporarily. Here, tree pollen decline at the expense of Poaceae $(22 \%)$. Again, an individual disturbance event could have caused this decline. On the other hand, it is striking that it also coincides with a coldhumid phase, namely CE-8 (800-400 BC) (Haas et al., 1998).
This youngest pollen zone is characterized by a modest increase in pollen taxa that indicate human land use. Poaceae reach more than $10 \%$ after $1000 \mathrm{BC}$, and individual pollen grains of Plantago lanceolata-type, Rumex and Humulus/ Cannabis-type were found. However, no herb pollen apart from Poaceae ever exceeds $2 \%$ - such a percentage can also be achieved by mere long-distance transport from the lowlands. Furthermore, Cerealia pollen is entirely absent. By Central European standards, this reflects a very low human impact on the landscape. It seems that the Fuorn Valley is situated at too high an altitude (c. $1800 \mathrm{~m}$ a.s.l.) and at the same time too remote from a lower valley for early settlers to use the land regularly for grazing or even for tillage. At most, livestock might have been occasionally brought up here during summer. Timber exploitation in the Fuorn Valley is documented for the past few centuries (Parolini, 1995), but no significant effect of forestry on the species composition can be detected. Eventually, the temporal resolution chosen for pollen analysis may be too coarse for this purpose.

\section{Vegetation history of Fuldera}

In contrast to the situation at Il Fuorn, pollen analysis revealed that the mire Fuldera-Palü Lunga was surrounded by Norway spruce (Picea abies) forests most of the time (Figure 6). In 30 samples from this stratigraphy, a total of 71 pollen and spore types from terrestrial plants, six fern taxa and three aquatic and moorland plants were identified by pollen analysis. Numerical zonation revealed five local pollen assemblage zones (LPAZ). In addition, LPAZ Fu-5 was split up into subzones ( $\mathrm{Fu}-5 \mathrm{a} / \mathrm{Fu}-5 \mathrm{~b})$ because a clear difference in the pollen diagram could be seen.

LPAZ Fu-1 (150-115 cm, 4030-3020 BC) shows a high abundance of Picea abies pollen (60-80\%). Pollen percentages of other coniferous tree species are instead rather low, with a maximum of $15 \%$ for Pinus sylvestris/mugo-type, $6 \%$ for Pinus cembra and 1\% for Larix decidua. Tree and shrub pollen add up to over $90 \%$ of the terrestrial pollen found. Picea abies thus was the dominant tree species on the southern slope of the Müstair Valley and grew in closed and almost pure stands. Contrary to the situation in Il Fuorn, it remains uncertain whether Pinus sylvestris/mugo-type pollen is evidence for $P$. mugo or for P. sylvestris in Fuldera, as no needles suitable for cross-sections could be found.

LPAZ Fu-2 (115-113 cm, 3020-2970 BC) consists of only one sample at $114 \mathrm{~cm}$ depth. It is characterized by a huge pollen percentage of Alnus viridis (74\%) and a much lower abundance of Picea abies pollen (22\%) than in the previous zone. According to this, the forest canopy literally collapsed, and green alder shrubberies developed instead. It seems probable that this temporary shift in vegetation was linked to the proceeding Central European cold-humid phase CE-6 (3360-3020 BC) (Haas et al., 1998), the more so as a later peak of Alnus viridis pollen ( $\mathrm{Fu}-4)$ again coincides with a coldhumid phase. However, a local disturbance event would also explain this breakdown of the forest canopy.

During LPAZ Fu-3 (113-88 cm, 2970-1600 BC), Picea abies pollen again continuously reaches percentages of over $60 \%$. Moreover, numerous needles of Picea abies were found in the macrofossil samples. Percentages of Pinus sylvestris/mugo pollen type vary between $10 \%$ and $20 \%$. Other coniferous tree pollen, however, were found only sporadically $(>1 \%)$. Consequently, closed Norway spruce forest re-established after the collapse at c. $3000 \mathrm{BC}$ and continued to cover the area until c. $1600 \mathrm{BC}$, when they were again replaced by green alder shrubberies. In all three samples within LPAZ Fu-4 $(88-80 \mathrm{~cm}$, $1600-1080$ BC), Alnus viridis pollen exceeded $65 \%$. 


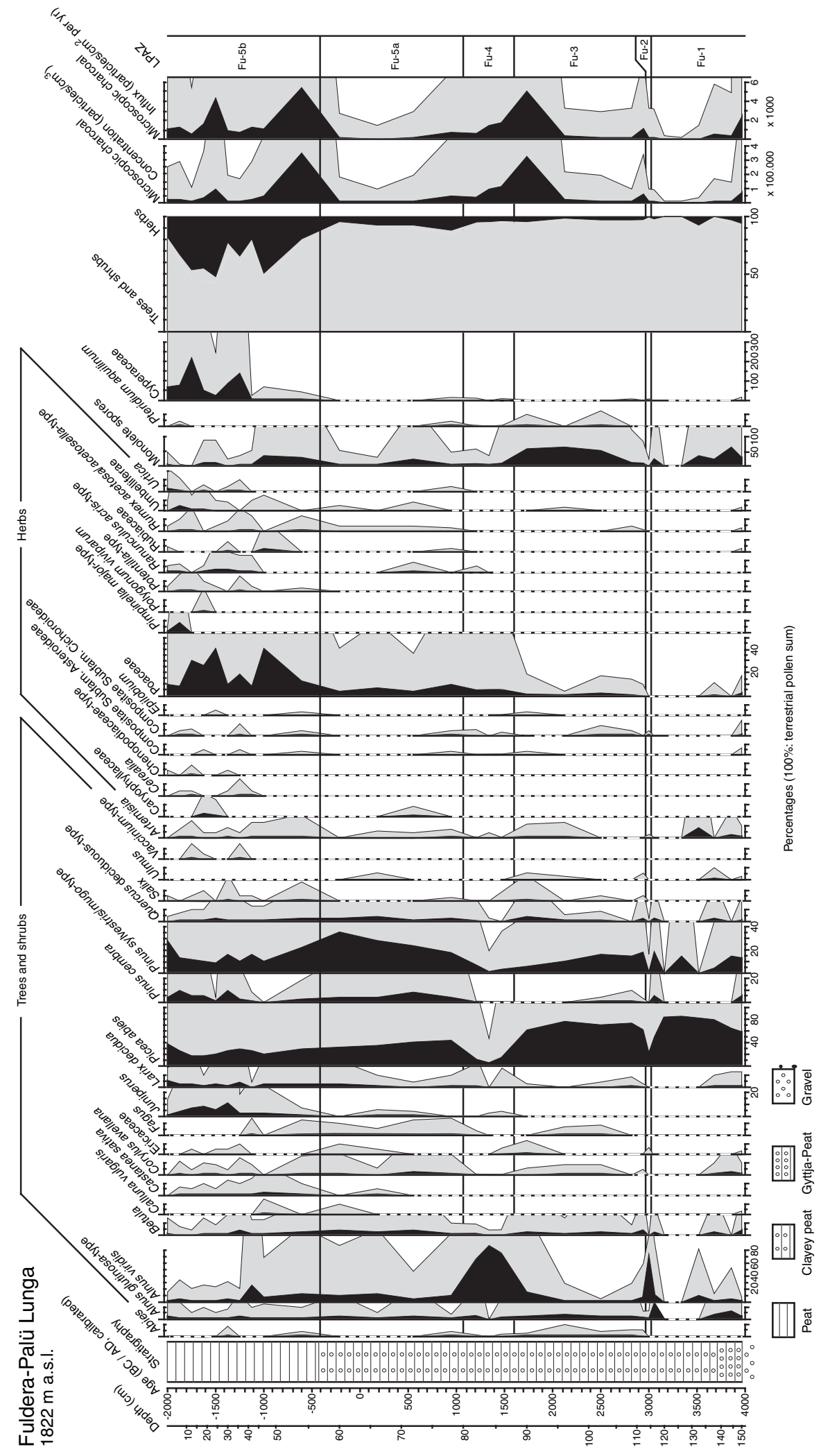

Figure 6 Pollen percentages of selected taxa as well as microscopic charcoal concentration and influx for Fuldera. Analysis: W. Finsinger (Pollen), M. Stähli (Charcoal)

At the beginning of LPAZ Fu-5a $(80-57 \mathrm{~cm}, 1080 \mathrm{BC}-\mathrm{AD}$ $410)$, tree pollen again become prevalent. In the course of this subzone, Picea abies pollen steadily decreases from $44 \%$ to $30 \%$ whereas Pinus sylvestris/mugo-type pollen increases from $17 \%$ to $35 \%$. Further, Fu-5a shows the highest percentages of Pinus cembra (between $3 \%$ and $8 \%$ ) as well as Larix decidua pollen (between $1 \%$ and $2 \%$ ). Therefore, the vegetation can be referred to as mixed spruce forests. A slight increase of Poaceae pollen possibly suggests first relevant effects of land use on species composition.

A characteristic of LPAZ Fu- $5 \mathrm{~b}(57-0 \mathrm{~cm}, \mathrm{AD} 410$-present) is the appearance of pollen types commonly known to indicate human activity, including both livestock farming and tillage (eg, Cerealia, Juniperus, Pimpinella major-type Ranunculus acris-type, or Urtica; Behre, 1981; Lang, 1994; Burga and Perret, 1998). Strong increases of Poaceae pollen (up to 40\%) 
Table 2 Overview of mean fire-return intervals (MFI) and influx of microscopic charcoal (particles/ $\mathrm{cm}^{2}$ per yr) in selected sections of the sediment (the analysis considers only layers consisting of organic sediments; all gravel layers were excluded)

\begin{tabular}{|c|c|c|c|c|}
\hline Sediment section & Pollen zones & MFI & $\begin{array}{l}\text { Number of } \\
\text { fire events }\end{array}$ & $\begin{array}{l}\text { Microscopic charcoal, influx } \\
\text { (particles } / \mathrm{cm}^{2} \text { per yr) }\end{array}$ \\
\hline \multicolumn{5}{|l|}{ Il Fuorn } \\
\hline Entire record & - & 440 & 14 & 610 \\
\hline Older sediment section (before $2390 \mathrm{BC}$ ) & Il-1 to Il-6 & 350 & 9 & $605\left(665^{\mathrm{a}} / 440^{\mathrm{b}}\right)$ \\
\hline Younger sediment section (after $1020 \mathrm{BC}$ ) & Il-7 & 605 & 5 & 635 \\
\hline \multicolumn{5}{|l|}{ Fuldera } \\
\hline Entire record & - & 505 & 12 & \\
\hline Phase before intensive human land use (before AD 410) & $\mathrm{Fu}-1$ to $\mathrm{Fu}-5 \mathrm{a}$ & 740 & 6 & 975 \\
\hline Phase with intensive human land use (after AD 410) & $\mathrm{Fu}-5 \mathrm{~b}$ & 265 & 6 & 1900 \\
\hline \multicolumn{5}{|l|}{ Vegetation specific analyses } \\
\hline Mountain-pine forests & Il-1, Il-3, Il-4, Il-5 & 230 & 8 & 530 \\
\hline Mixed forests & $\mathrm{Il}-2, \mathrm{Il}-6$ & $(>600)$ & 1 & 690 \\
\hline Norway spruce forests & Fu-1, Fu-3 & 595 & 4 & 1110 \\
\hline
\end{tabular}

a $6230-4110$ BC.

b $2990-2390$ BC

as well as the presence of numerous herb seeds in the macrofossil record (mainly from Chenopodium album and Stellaria alsine) are most probably caused by livestock farming. Further, the occurrence of Castanea sativa pollen (sweet chestnut) is connected with the introduction of chestnut cultivation during the Roman period in the Insubrian lowlands across the Swiss-Italian border (Conedera et al., 2004). Altogether, human impact at Fuldera is clearly stronger than at Il Fuorn, although it started at least 1000 years later in Fuldera than at similar altitudes (1500-1800 m a.s.1.) in the Engadine valley (Zoller et al., 1996; Gobet et al., 2003).

\section{Regional fire history of Il Fuorn}

Empirical studies have shown that microscopic charcoal can be used to reconstruct past regional fire activities (ie, within 20 $100 \mathrm{~km}$ around the site; MacDonald et al., 1991; Tinner et al., 1998). We regard microscopic charcoal particles $(>10 \mu \mathrm{m})$ as an evidence for fires in the upper catchment area of the Fuorn Valley (see map in Figure 1). As the valley is surrounded by high mountain ridges, it seems unlikely that a large number of particles were introduced by long-distance transport, even though the catchment area amounts to $c .40 \mathrm{~km}^{2}$ only.

Microscopic charcoal concentration and influx were determined in 35 samples (Figure 3). Generally, they show influx values of 200 to 800 particles (particles $/ \mathrm{cm}^{2}$ per yr) with an average of 610 particles $/ \mathrm{cm}^{2}$ per yr. Converted into surface area, this corresponds to values between 0.1 and $0.3 \mathrm{~mm}^{2} / \mathrm{cm}^{2}$ per yr when the regression model by Tinner and $\mathrm{Hu}(2003)$ is used.

To outline the results, the microscopic charcoal curve can be divided into three sections. Fire activity was relatively high before 4000 BC. In the lowest part of the sediment, the mean charcoal influx reaches 665 particles $/ \mathrm{cm}^{2}$ per yr (Table 2). Afterwards, the accumulation decreases to 440 particles $/ \mathrm{cm}^{2}$ per $\mathrm{yr}$ on average in the period from 3000 to $2400 \mathrm{BC}$. This decline is likely to have been caused by climate change, for summers became colder and, more importantly, wetter between 3500 and 2500 BC (Tinner and Theurillat, 2003). The appearance of Pinus cembra pollen provides further indication for a cooling transition. In the youngest sediment section (after 1020 $\mathrm{BC}$ ), charcoal influx again increased to 635 particles $/ \mathrm{cm}^{2}$ per yr on average, probably because of to intensified human land use at regional level.

\section{Regional fire history of Fuldera}

Microscopic charcoal concentration and influx were determined in 30 samples. They contained an average of 1305 particles $/ \mathrm{cm}^{2}$ and year (particles $/ \mathrm{cm}^{2}$ per yr), but most individual influx values range from 300 to 1200 particles $/ \mathrm{cm}^{2}$ per yr (Figure 6). Using the regression model by Tinner and $\mathrm{Hu}$ (2003), we estimate the surface area influx at 0.12 to 0.45 $\mathrm{mm}^{2} / \mathrm{cm}^{2}$ per yr. Two samples $(120 \mathrm{~cm}, 126 \mathrm{~cm})$ were excluded from these calculations because both charcoal and pollen concentration were very low and the counting is based on too few particles.

Accumulation of microscopic charcoal particles is generally higher in the younger sediment section. Influx averages 1900 particles $/ \mathrm{cm}^{2}$ per yr in LPAZ Fu-5b (after AD 410), compared with 975 particles $/ \mathrm{cm}^{2}$ per yr before (Table 2). This increase in regional fire activity was most probably caused by intensification of human activities.

The regional setting suggests that the vast majority of microscopic charcoal particles $(>10 \mu \mathrm{m})$ found in the core 'Fuldera' originate from fires in the upper part of the Müstair Valley (west of Santa Maria; see map in Figure 1).

\section{Local fire history of Il Fuorn}

Macroscopic charcoal concentration and influx are presented in Figure 4. Charcoal particles were found over the whole core, exept for the gravel layers. Concentration is highest in the oldest part of the core. Yet many individual samples contain no charcoal at all. Fourteen residual peaks were identified on the basis of the smoothed influx curve and according to the method described in the section 'material and methods' (Figure 5). Five additional peaks can be seen in the curve, but here charcoal concentration did not reach the specified threshold values. Fire-return intervals ranged strongly from a minimum of 54 years up to 900 years, with an average of 440 years (Table 2).

Fires were more frequent in the early and middle Holocene than afterwards. The mean fire-return interval (MFI) drops to 350 years when only the older sediment sections (before 2390 BC) are considered. In contrast, the late Holocene shows a value of 605 years, as only five local fires have occurred since 1000 вс. Climatic influence seems evident also in respect of fire frequency, as the reduction of fire activity corresponds with the decline of microscopic charcoal influx around 2700 BC. Furthermore, the extension of fire intervals reinforces the 


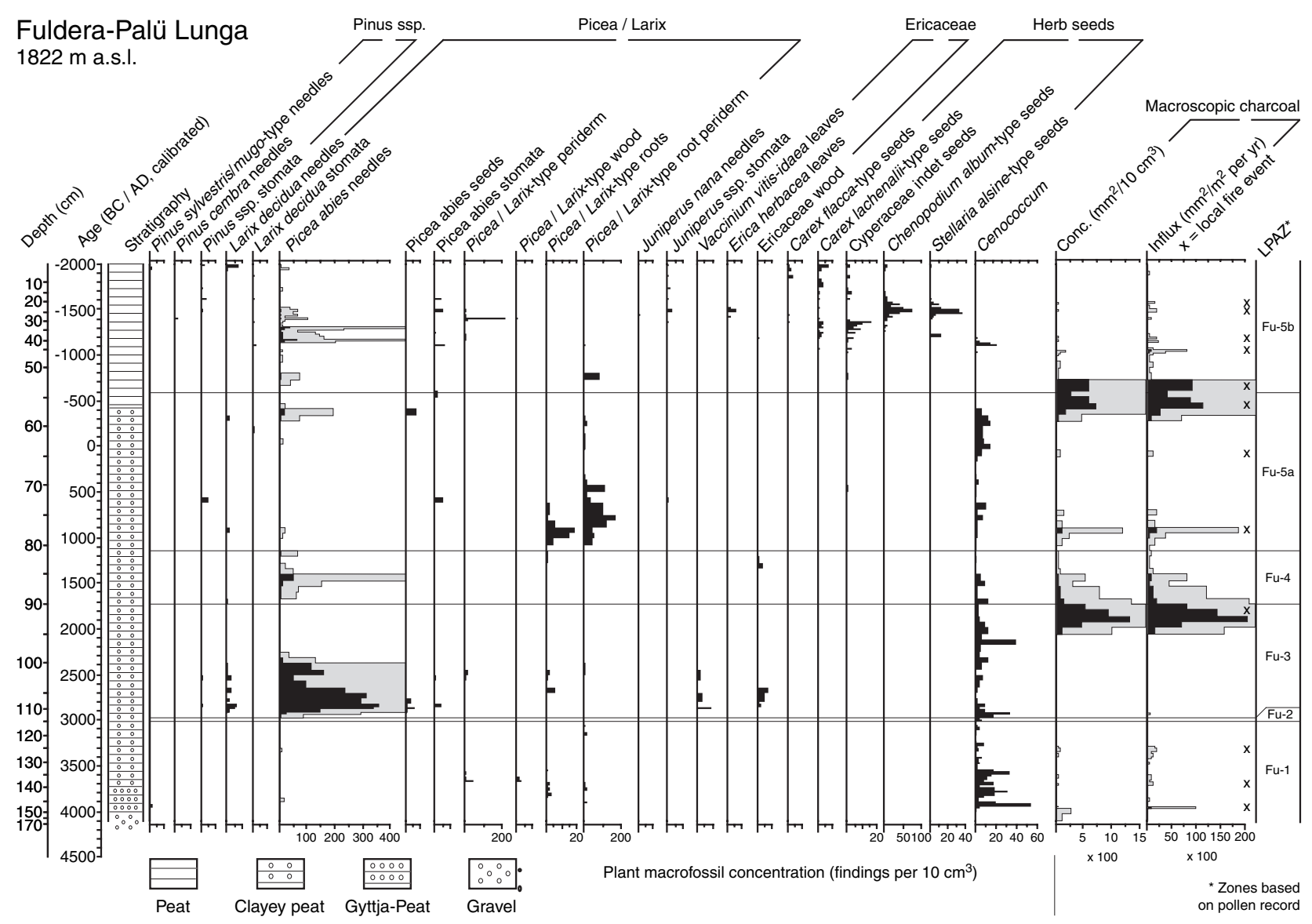

Figure 7 Diagram showing selected plant macrofossil concentrations as well as macroscopic charcoal concentration and influx for Fuldera. Analysis: M. Stähli

view that agricultural land use (pasture farming and tillage) was very limited around Il Fuorn. However, we know from historical sources that during the past few centuries timber was exploited intensively for ore smelting and exportation (mainly to the salt-mine in Hall, Tirol) (Parolini, 1995). Our results suggest that timber exploitation did not cause an increase in fires, but actually prevented fuel build-ups that would favour fire ignition and intensity.

\section{Local fire history of Il Fuldera}

Concentration and influx of macroscopic charcoal for Fuldera are shown in Figure 7. Influx values remain low $\left(<1000 \mathrm{~mm}^{2} /\right.$ $\mathrm{m}^{2}$ per $\mathrm{yr}$ ) from $4000 \mathrm{BC}$ to $2000 \mathrm{BC}$. After this, the charcoal record is characterized by two phases of massive accumulation (c. $1800 \mathrm{BC}$ and $\mathrm{AD} 500$ ). However, curve smoothing revealed a total of 12 residual peaks and thus 12 fire events (Figure 8). The resulting fire-return intervals are as different as the ones at Il Fuorn. On average over the whole profile, wildfires occurred every 505 years. However, frequency was inconstant over time: half of the fire events (six out of twelve) occurred after AD 410 (ie, within LPAZ Fu-5b). Consequently, an MFI of 265 years after AD 410 compares with only 740 years in the period from 4030 BC until AD 410. Human activities are very likely to have caused the increase in regional fire activity, the more so as it is in accordance with both pollen and microscopic charcoal results.

\section{Fire history and forest type}

The chosen multiproxy approach enables the investigation of fire activity with respect to different vegetation types. We divided sediment sections of both cores (Il Fuorn and Fuldera) into three distinct groups characterized by similar vegetation types. 'Mountain-pine forests' correspond to pollen zones in which Pinus mugo ssp. uncinata is the dominant tree species (LPAZ Il-1, Il-3, Il-4 and Il-5). Sections with high percentages of both Picea abies and Pinus mugo-type pollen are referred to as 'mixed forests' (LPAZ Il-2 and Il-6), whereas 'Norway spruce forests' include LPAZ Fu-1 and Fu-3 ( $>60 \%$ Picea abies pollen). (Pollen zones containing evidence of human activities are not included in this comparison.) Subsequently, the MFI was calculated for each individual group.

Fires were most frequent in mountain-pine forests with an MFI of 230 years compared with 595 years in Norway spruce forests (Table 2). This difference is hardly coincidental, even if the MFI data result from only five or four fire events, respectively. During the periods with mixed forests, which lasted for $c .1000$ years in total, only one fire event occurred. Although no MFI value can be calculated, this suggests that fire frequency in mixed forests was also low.

In contrast, in Norway spruce forests (1110 particles $/ \mathrm{cm}^{2}$ per yr on average), more microscopic charcoal was deposited than in mountain-pine forests (530 particles $/ \mathrm{cm}^{2}$ per yr), whereas accumulation was intermediate between these two in mixed forest (690 particles $/ \mathrm{cm}^{2}$ per yr). Stands dominated by Pinus mugo ssp. uncinata clearly burned more often than spruce stands. However, we presume that the individual fire events were less severe.

\section{Fire-induced changes in vegetation}

The investigation of short-term vegetational changes in this study remains preliminary because of the fairly coarse temporal resolution of the pollen analyses. Nevertheless, we were able to track changes after seven distinct local fire events (Il Fuorn: 39, 99, 182 and $197 \mathrm{~cm}$ depth; Fuldera: 45, 56 and 92 

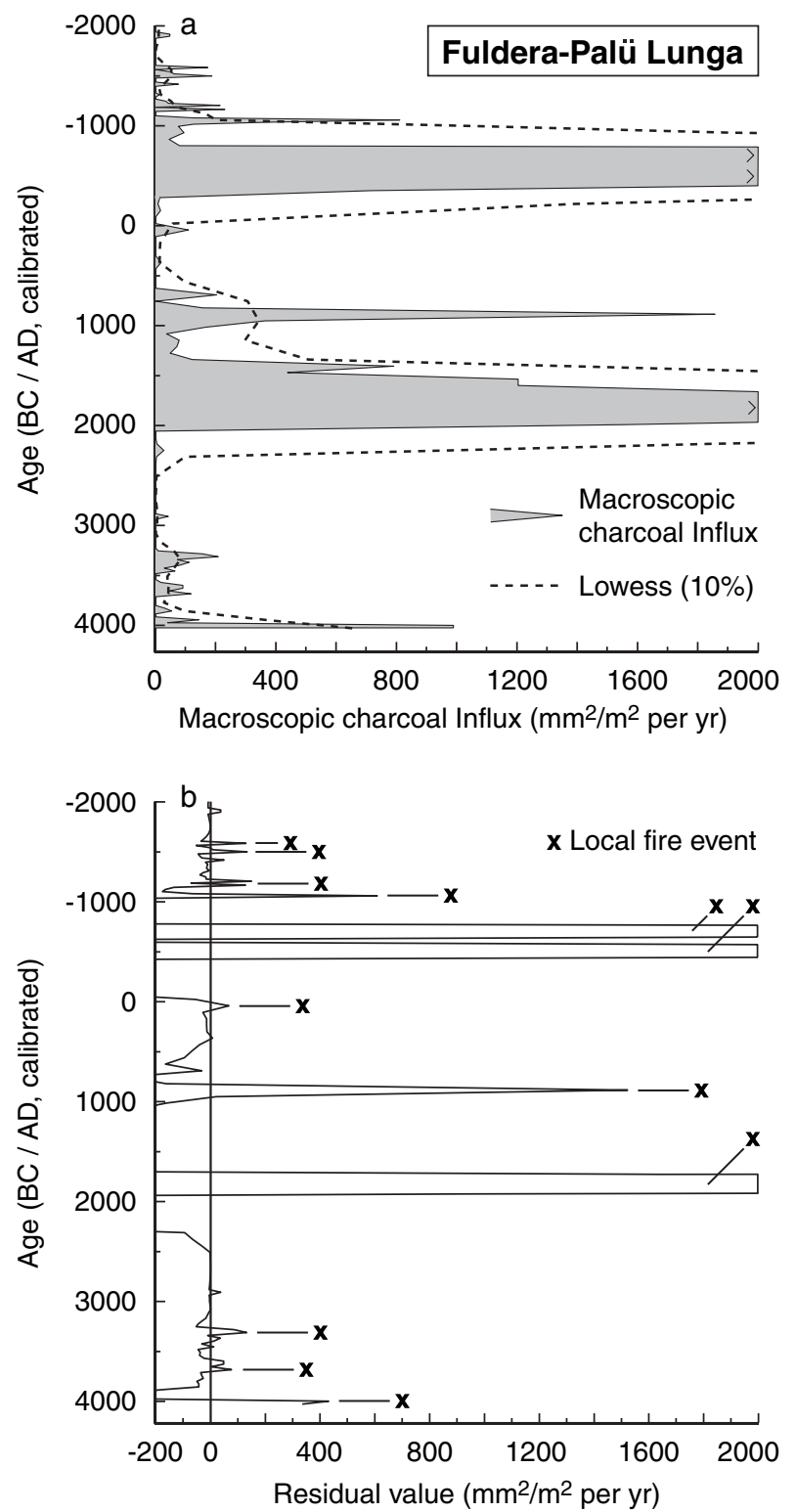

Figure 8 (a) Smoothed curve of macroscopic charcoal influx for Fuldera (Lowess; span $=10 \%$ ). (b) Residual peaks (difference between influx and smoothed values) that were interpreted as local fire events

$\mathrm{cm}$ depth). Following fires, prominent rises and drops in pollen percentages were observed. Pollen types that increased most often were Salix (in five cases), Alnus viridis (four), Cyperaceae (three), Epilobium (three) and Pteridium aquilinum (three). These species were previously found to sprout well after Holocene fires (Tinner et al., 1999; Gobet et al., 2003) and recent burns (Delarze et al., 1992; Schönenberger and Wasem, 1997). Pollen of Pinus mugo/sylvestris-type twice shows a postfire rise and a drop in one case. Picea abies pollen both increases and decreases twice. According to this, forest fires favoured the above-named shrubs and herbs but did not affect the tree composition within the remaining forests in the short term.

\section{Discussion}

\section{Fire history and fire ecology}

Macroscopic charcoal analysis is considered a suitable method to reconstruct local fire history and to estimate mean firereturn intervals (MFI) (Long et al., 1998; Millspaugh and
Whitlock, 1995; Whitlock and Larsen, 2001). The most critical point is probably to define a threshold of charcoal accumulation that is still regarded to represent a fire event. In this study, all fire events are based on sediment samples with a charcoal concentration of at least $3 \mathrm{~mm}^{2} / 10 \mathrm{~cm}^{3}$. Further, all of these samples contain several particles $>1 \mathrm{~mm}$ in diameter. According to Clark and Patterson (1997), the vast majority of charcoal fragments in this size class are deposited near a fire $(<100 \mathrm{~m})$, which means that the MFI presented in this paper are very unlikely to be underestimated.

The MFI in the surroundings of the Swiss National Park (SNP) (down to 250 years in mountain-pine forests) turn out to be shorter than the few previous fire history studies in the Alps might suggest.

For southern Switzerland, at the edge of the Alps, a natural MFI of c. 1500 years has been proposed (Berli et al., 1994, Tinner et al., 1999; Allgöwer et al., 2003). In our opinion, the difference between this situation and that around the Swiss National Park (SNP) is due to the fact that southern Switzerland is partly covered by broadleaved forests, which are generally less fire-prone (Pyne et al., 1996).

Further, in soils of the dry, inner alpine Maurienne Valley (France) with a climatic setting comparable with the SNP, Carcaillet (1998) did not find charcoal particles from the period before anthropogenic deforestation started. This contradicts the results of our study, and the question is whether stratified deposits such as peat or lake sediments would have revealed natural fires. However, comparable natural fire intervals (200 to 600 years) are indicated by a macroscopic charcoal time series from Lago Basso (Italy), although MFI were not calculated explicitly in this study (Wick and Tinner, 1997). Lago Basso, situated c. $70 \mathrm{~km}$ southwest of the SNP, also represents an inner alpine site surrounded by coniferous forests (mainly Pinus cembra and Larix decidua).

Shorter fire intervals in mountain-pine forests (Pinus mugo ssp. uncinata, 230 years) compared with Norway spruce forests (Picea abies, $>600$ years) are not a surprise, given the fact that Pinus sylvestris, a relative of Pinus mugo, is considered the most fire-tolerant tree in the boreal forests of Europe (Sannikov and Goldammer, 1996; Agee, 1998). These two pine species may react similarly to fire (Tapias et al., 2004). Allgöwer et al. (1998), on the basis of fuel sampling, likewise concluded that mountain-pine forests are more susceptible to forest fires than are other coniferous forest communities in the SNP. But altogether, there has been little research on fire ecology of P. mugo ssp. uncinata.

Further, similar outward appearance and habitats (severe microclimate/infertile soils) lend themselves to compare Pinus mugo ssp. uncinata with the North American Pinus contorta (lodgepole pine). Forests dominated by $P$. contorta support fires ranging from crown fires to slow-spreading smouldering fires and show an MFI of c. 60 to 80 years (Agee, 1998), which is clearly shorter than for P. mugo ssp. uncinata.

In our opinion, fire events identified in this study also represent a mixture of crown fires and surface fires-particularly in mountain-pine forests-for the following reasons. First, the pollen record suggests that fire did not significantly modify the occurrence of tree species on a short-term basis but did affect the dispersion of shrub and herb species-a situation likely to be observed after surface fires. Second, forest regeneration after severe crown fires can be very slow in subalpine environments, particularly on steep slopes and when soil material is destroyed (Schönenberger and Wasem, 1997). Thus these forests seem unlikely to have supported severe crown fires at intervals of 300 years. Similarly, Tapias et al. (2004) claim that late flowering and absence of serotiny 
indicate that both $P$. mugo ssp. uncinata and P. sylvestris do not develop with frequent crown fires. We propose to assign the forests in the SNP to moderate fire regimes, as Agee (1998) did for $P$. sylvestris. Moderate fire regimes are characterized by the occurrence of both crown and surface fires.

\section{Fire history, human land use and climate}

Earliest evidence of grazing activities in the valley bottom of the Engadine dates back to $c .3600 \mathrm{BC}$, whereas there are no signs of crop farming until as late as c. $2000 \mathrm{BC}$ (Zoller et al., 1996; Gobet et al., 2003). According to our pollen results, agricultural activities appear to have started even later (Fuldera: $c .1100 \mathrm{BC}$ ) or to have been almost absent until the present day (Il Fuorn) in the vicinity of our study sites. Thus the fire intervals that are based on the older parts of the cores can, in fact, be considered natural. Fire activity clearly increased with intensified land use in Fuldera (Table 2). Hunter-gatherer societies certainly had sporadically visited high-altitude areas in the Alps during the Mesolithic (Fedele, 1999; Pignat and Crotti, 2002) and might have caused single fires-deliberately or unintentionally. However, at a regional scale the effect of man on the pre-agricultural landscape can be neglected. Accordingly, Whitlock and Knox (2002) claim that fire activity before Euro-American settlement in the northwestern USA was largely controlled by climate, not by Native American hunting practices. At Il Fuorn, fire frequency decreased between 3500 and $2500 \mathrm{BC}$, most probably for climatic reasons (Table 2), even if some tens of kilometres away the first herdsmen left their marks in the Engadine.

In conclusion, this study supports the point of view that fire is in fact a natural process in the (Central) Alps, a view that has only recently been proposed (eg, Berli et al., 1994; Tinner et al., 1998; Allgöwer and Gleason, 2001; Allgöwer et al., 2003). Although our results cannot be generalized to the whole Central Alps, especially not to areas covered with different forest type, there is strong evidence that the dry, inner alpine valleys all have their natural fire histories.

\section{Potential vegetation of the Fuorn Valley}

So far it has commonly been assumed that the vast mountainpine forests around Il Fuorn reflect an early-successional state resulting from extensive clear-cuts in the late nineteenth century and will gradually be replaced by Swiss stone pine/ larch communities in the future (Pinus cembralLarix decidua) (Parolini, 1995; Zoller, 1995; Risch et al., 2004). Our pollen and macrofossil records, however, suggest that Pinus mugo ssp. uncinata had a strong natural potential during the Holocene and represented the dominant tree in forests that were composed of varying proportions of Pinus cembra, Larix decidua and Picea abies. In contrast, Pinus cembra was much less widespread than, for example, in the Upper Engadine Valley (Gobet et al., 2003). These results support an earlier statement by Ellenberg (1986), who presumed that, 'due to low precipitation (by alpine standards) and infertility of the prevailing dolomite soils, probably some of the extensive mountain-pine stands had already existed before human interference'. Dominating occurrence of Pinus mugo ssp. uncinata in the Holocene has previously been reported from the French Alps by Ponel et al. (1992) and Ali et al. (2004).

On the basis of their investigation of forest succession in the SNP, Risch et al. (2004) conclude that, after a clear-cut, a minimum of 205 to 235 years is required to reach the latesuccessional Swiss stone pine/larch forest, which replaced the early-successional mountain-pine forest. Coincidentally, this is exactly the duration of the mean fire-return interval we proposed for mountain-pine forests (Table 2). It seems that forests in the Holocene in the Fuorn Valley hardly ever reached a late-successional stage (ie, Pinus cembralLarix decidua) as proposed by Risch et al. (2004). Instead, our results suggest that fire disturbance and the particular environmental conditions (dry continental climate, dolomite bedrock) allowed mountain-pine stands to persist in the Swiss National Park throughout the mid and late Holocene.

\section{Acknowledgements}

This work was funded by the GIS of the Swiss National Park (GIS-SNP), the EU project 'Firelab' (EC-Contract No. EVR1CT-2002-40028, Swiss Office of Science and Education Contract No. 02.0008) and the Palaeoecology Group at the Institute of Plant Science, University of Bern (Brigitta Ammann). The GIS division at the Department of Geography, University of Zurich, supported AMS radiocarbon dating (Robert Weibel).

The last author would like to acknowledge in particular the late Paul Gleason-famous fire fighter and long-time prescribed burning specialist of the USDA Forest Service. Investigating the present fuel situation in the Swiss National Park, he put us on track to investigate the true nature of fire in this area: 'If you want to know what goes on here, you need to look deep into fire history'.

We are grateful to the Swiss National Park, the canton of Grisons and the community of Fuldera for permissions for coring and would like to thank everybody who helped with fieldwork and in the laboratory, or otherwise contributed to our research: Michael Bur, Erika Gobet, Petra Kaltenrieder, Horst Machgut, Florencia Oberli, Marie-Pierre Rogeau, Michael Studer and Willi Tanner.

\section{References}

Agee, J.K. 1998: Fire and pine ecosystems. In Richardson, D.M., editor, Ecology and biogeography of Pinus. Cambridge University Press, 193-218.

Ali, A.A., Roiron, P., Guendon, J.-L. and Terral, J.-F. 2004: Subalpine vegetation dynamics in the Southern French Alps during the Holocene: evidence from plant imprints and charcoal preserved in travertine sequences. Arctic, Antarctic and Alpine Research 36, 42-48.

Allgöwer, B. and Gleason, P. 2001: Assessing the (re-) introduction of fire into the Swiss National Park: implications and challenges. Tall Timbers 22nd Fire Ecology Conference, Kananaskis Village, Canada, 15-18 October 2001, unpublished.

Allgöwer, B., Harvey, S. and Rüegsegger, M. 1998: Fuel models for Switzerland: description, spatial pattern, index for crowning and torching. In Viegas, D.X., editor, Proceedings of the $3 \mathrm{rd}$ International Conference on Forest Fire Research/14th Conference on Fire and Forest Meteorology, Luso, Portugal. 16-20 November 1998. 2605-20.

Allgöwer, B., Bur, M., Stähli, M., Koutsias, N., Tinner, W., Conedera, M., Stadler, M. and Kaltenbrunner, A. 2003: Can long-term wildland fire history help to design future fire and landscape management? - An approach from the Swiss Alps. Proceedings of the 3rd Wildland Fire Conference and Exposition, Sydney, Australia. 3-6 October 2003. CDROM by AmLink Digital Services.

Behre, K.-E. 1981: The interpretation of anthropogenic indicators in pollen diagrams. Pollen et Spores 23, 225-45.

Bennett, K.D. 1996: Determination of the number of zones in a biostratigraphical sequence. New Phytologist 132, 155-70.

Bennett, K.D. and Willis, K.J. 2001: Pollen. In Smol, J.P., Birks, H.J.B. and Last, W.M., editors, Tracking environmental change 
using lake sediments. Volume 3: terrestrial, algal and siliceous indicators. Kluwer Academic Publishers, 5-32.

Berli, S., Cherubini, P. and Schoch, W. 1994: Rekonstruktion von Bestandesfluktuationen, Bodenmächtigkeit und Feuergeschichte über 7000 Jahre BP mittels Holzkohle-Analysen. Botanica Helvetica 104, 17-30.

Birks, H.H. and Birks, H.J.B. 2000: Future uses of pollen analysis must include plant macrofossils. Journal of Biogeography 27, 3135 .

Birks, H.J.B. and Gordon, A.D. 1985: Numerical methods in Quaternary pollen analysis. Academic Press.

Bradshaw, R.H.W., Tolonen, K. and Tolonen, M. 1997: Holocene records of fire from the boreal and temperate zones of Europe. In Clark, J.S., Cachier, H., Goldammer, J.G. and Stocks, B., editors, Sediment records of biomass burning and global change. NATO ASI Series 1: global environmental change. Vol. 51. Springer, 341-65. Burga, C.A. and Perret, R. 1998: Vegetation und Klima der Schweiz seit dem jüngeren Eiszeitalter. Ott.

Carcaillet, C. 1998: A spatially precise study of Holocene fire history, climate and human impact within the Maurienne Valley, North French Alps. Journal of Ecology 86, 384-96.

Carcaillet, C., Bouvier, M., Fréchette, B., Larouche, A.C. and Richard, P.J.H. 2001: Comparison of pollen-slide and sieving methods in lacustrine charcoal analyses for local and regional fire history. The Holocene 11, 467-76.

Clark, J.S. 1988a: Particle motion and theory of stratigraphic charcoal analysis: source area, transport, deposition and sampling. Quaternary Research 30, 67-80.

1988b: Stratigraphic charcoal analysis on petrographic thin sections: applications to fire history in northwestern Minnesota. Quaternary Research 30, 81-91.

Clark, J.S. and Patterson, W.A., III 1997: Background and local sediments: scales of fire evidence in the paleorecord. In Clark, J.S., Cachier, H., Goldammer, J.G. and Stocks, B., editors, Sediment records of biomass burning and global change. NATO ASI Series 1: Global environmental change, Vol. 51. Springer, 23-48.

Conedera, M., Krebs, P., Tinner, W., Pradella, M. and Torriani, D. 2004: The cultivation of Castanea sativa (Mill.) in Europe, from its origin to its diffusion on a continental scale. Vetetation History and Archeobotany 13, 161-79.

Delarze, R., Caldelari, D. and Hainard, P. 1992: Effects of fire on forest dynamics in southern Switzerland. Journal of Vegetation Science 3, 55-60.

Ellenberg, H. 1986: Vegetation Mitteleuropas mit den Alpen. Fourth edition. Ulmer.

Fedele, F.G. 1999: Economy and territory of high-altitude mesolithic land use: the Central Alps. In Della Casa, Ph., editor, Prehistoric alpine environment, society and economy. Papers of the international colloquium PAESE '97 in Zurich, Universitätsforschungen zur prähistorischen Archäologie 55, 131-64.

Gobet, E., Tinner, W., Hochuli, P.A., van Leeuwen, J.F.N. and Ammann, B. 2003: Middle to late Holocene vegetation history of the Upper Engadine (Swiss Alps): the role of man and fire. Vegetation History and Archaeobotany 12, 143-163.

Godet, J.-D. 1983: Knospen und Zweige der einheimischen Baumund Straucharten. Arboris Verlag.

1998: Einheimische Bäume und Sträucher. Arboris Verlag.

Haas, J.N., Richoz, I., Tinner, W. and Wick, L. 1998: Synchronous Holocene oscillations recorded on the Swiss Plateau and at timberline in the Alps. The Holocene 8, 301-309.

Lang, G. 1994: Quartäre Vegetationsgeschichte Europas. Methoden und Ergebnisse. Gustav Fischer.

Langhart, R., Bachmann, A. and Allgöwer, B. 1998: Spatial and temporal patterns of fire occurrence (Canton of Grison, Switzerland). In Viegas, D.X., editor, Proceedings of the 3rd International Conference on Forest Fire Research/14th Conference on Fire and Forest Meteorology, Luso, Portugal. 16-20 November 1998, 2279-92.

Latalowa, M. 1999: Paleoecological reconstruction of the environmental conditions and economy in early medieval Wolin. Acta Paleobotanica 39, 183-271.

Lauber, K. and Wagner, G. 1996: Flora Helvetica. Haupt.
Lévesque, P.E.M., Dinel, H. and Larouche, A. 1988: Guide to the identification of plant macrofossils in Canadian peatlands. Agriculture Canada, Publication No. 1817.

Long, C.J., Whitlock, C., Bartlein, P.J. and Millspaugh, S.H. 1998: A 9000-year fire history from the Oregon coast range, based on a high-resolution charcoal study. Canadian Journal of Forest Research 28, 774-87.

Lynch, J.A., Hollis, J.L. and Hu, F.S. 2004: Climatic and landscape controls of the boreal forest fire regime: Holocene records from Alaska. Journal of Ecology 92, 477-89.

MacDonald, G.M., Larsen, C.P.S., Szeicz, J.M. and Moser, K.A. 1991: The reconstruction of boreal forest fire history from lake sediments: a comparison of charcoal, pollen, sedimentological, and geochemical indices. Quaternary Science Reviews 10, 53-71. Merkt, J. and Streif, H.J. 1970: Stechrohr-Bohrgerät für limnische und marine Lockersedimente. Geologische Jahrbücher 88, 137-48. Millspaugh, S.H. and Whitlock, C. 1995: A 750-years fire history based on lake sediment records in central Yellowstone National Park, USA. The Holocene 5, 283-92.

Mohr, J.A., Whitlock, C. and Skinner, C.J. 2000: Postglacial vegetation and fire history, eastern Klamath Mountains, California. The Holocene 10, 587-601.

Moore, P.D., Webb, J.A. and Collinson, M.E. 1991: Pollen analysis. Second edition. Blackwell.

Nationalparkgesetz 1980: Bundesgesetz über den Schweizerischen Nationalpark im Kanton Graubünden (Nationalparkgesetz) vom 19 Dezember 1980. (Federal Law on the Swiss National Park). Federal Law Nr. SR 454.

Oswald, W.W., Anderson, P.M., Brown, T.A., Brubaker, L.B., Hu, F.S., Lozkin, A.V., Tinner, W. and Kaltenrieder, P. 2005: Effects of sample size and type on radiocarbon dating of arctic and subarctic lake sediments. The Holocene 15, 758-67.

Parolini, J.D. 1995: Zur Geschichte der Waldnutzung im Gebiet des heutigen Schweizerischen Nationalparks. PhD Thesis, ETH Zurich.

Patterson, W.A., III, Edwards, K.J. and Maguire, D.J. 1987: Microscopic charcoal as a fossil indicator of fire. Quaternary Science Reviews 6, 3-23.

Pignat, G. and Crotti, P. 2002: Die Besiedlung des Alpenraumes. In Curdy, P. and Praz, J.-C., editors, Die ersten Menschen im Alpenraum von 50.000 bis 5000 vor Christus. Verlag NZZ, 69-88. Pitkänen, A., Huttunen, P., Jungner, H. and Tolonen, K. 2002: A 10000 year local forest fire history in a dry heath forest site in eastern Finland, reconstructed from charcoal layer records of a small mire. Canadian Journal of Forest Research 32, 1875-80.

Ponel, Ph., Beaulieu, de J.-L. and Tobolski, K. 1992: Holocene palaeoenvironments at the timberline in the Taillefer Massif, French Alps: a study of pollen, plant macrofossils and fossil insects. The Holocene 2, 117-30.

Pyne, S.J., Andrews, P.L. and Laven, R.D. 1996: Introduction to wildland fire. Second edition. John Wiley.

Reille, M. 1992: Pollen et spores d'Europe et d'Afrique du Nord. Laboratoire de botanique historique et palynologie.

— 1995: Pollen et spores d'Europe et d'Afrique du Nord. Supplement 1. Laboratoire de botanique historique et palynologie.

Risch, A.C., Schütz, M., Krüsi, B.O., Kienast, F., Wildi, O. and Bugmann, H. 2004: Detecting successional changes in long-term empirical data from subalpine conifer forests. Plant Ecology 172, 95-105.

Sannikov, S.N. and Goldammer, J.K. 1996: Fire ecology of pine forests of Northern Eurasia. In Goldammer J.G. and Furyaev, V.V., editors, Fire in ecosystems of boreal Eurasia. Kluwer Academic Publishers, 151-67.

Schoch, W., Pawlik, B. and Schweingruber, F.H. 1988: Botanische Makroreste, ein Atlas zur Bestimmung häufig gefundener und ökologisch wichtiger Pflanzensamen. Haupt.

Schönenberger, W. and Wasem, U. 1997: Wiederbewaldung einer Waldbrandfläche in der subalpinen Stufe bei Müstair. Schweizerische Zeitschrift für Forstwesen 148, 405-24.

Stockmarr, J. 1971: Tablets with spores used in absolute pollen analysis. Pollen et spores 13, 615-21. 
Stuiver, M., Reimer, P.J., Bard, E., Beck, J.W., Burr, G.S., Hughen, K.A., Kromer, B., McCormac, F.G., van der Plicht, J. and Spurk, M. 1998: INTCAL98 radiocarbon age calibration, 24,000-0 cal BP. Radiocarbon 40, 1041-83.

Tapias, R., Climent, J., Pardos J.A. and Gil, L. 2004: Life histories of Mediteranean pines. Plant Ecology 171, 53-68.

Tinner, W. and Hu, F.S. 2003: Size parameters, size-class distribution and area-number relationship of microscopic charcoal: relevance for fire reconstruction. The Holocene 13, 499-505.

Tinner, W. and Theurillat, J.-P. 2003: Uppermost limit, extent, and fluctuations of the timberline and treeline ecocline in the Swiss Central Alps during the past 11.500 years. Arctic, Antarctic and Alpine Research 35, 158-69.

Tinner, W., Conedera, M., Ammann, B., Gäggeler, H.W., Gedye, S., Jones, R. and Sägesser, B. 1998: Pollen and charcoal analysis in lake sediments compared with historically documented forest fires in southern Switzerland since AD 1920. The Holocene 8, 31-42.

Tinner, W., Hubschmid, P., Wehrli, M., Ammann, B. and Conedera, M. 1999: Long-term forest fire ecology and dynamics in southern Switzerland. Journal of Ecology 83, 273-89.

Tobolski, K. 1992: Pflanzliche Makroreste in Seesedimenten und Torf. Bestimmungsschlüssel zum Praktikum Paläoökologie, Wintersemester 1992/93. Geobotanisches Institut der Universität Bern, unpublished.
Umbanhowar, C.E. and McGrath, M.J. 1998: Experimental production and analysis of microscopic charcoal from wood, leaves and grasses. The Holocene 8, 341-46.

Welten, M. 1982: Pollenanalytische Untersuchungen zur Vegetationsgeschichte des Scheizerischen Nationalparks. Ergebnisse der wissenschaftlichen Untersuchungen im Schweizerischen Nationalpark 16.

Whitlock, C. and Knox, M.A. 2002: Prehistoric burning in the Pacific Northwest. In Vale, T.R., editor, Fire, native people and the natural landscape. Island Press, 195-232.

Whitlock, C. and Larsen, C. 2001: Charcoal as a fire proxy. In Smol, J.P., Birks, H.J.B. and Last, W.M., editors, Tracking environmental change using lake sediments. Volume 3: Terrestrial, algal and siliceous indicators. Kluwer Academic Publishers, 75-97. Wick, L. and Tinner, W. 1997: Vegetation changes and timberline fluctuations in the Central Alps as indicators of Holocene climatic oscillations. Arctic and Alpine Research 29, 445-58.

Zoller, H. 1981: Pinaceae. In: Conert, H.J., editor, Gustav Hegi. Illustrierte Flora Mitteleuropas. Band I, Teil 2, Paul Parey, 32-104. _ 1995: Vegetationskarte des Schweizerischen Nationalparks, Erläuterungen. Nationalparkforschung in der Schweiz 85.

Zoller, H., Erny-Rodmann, Ch. and Punchakunnel, P. 1996: The history of vegetation and land use in lower Engadine (Switzerland). Pollen record of the last 13000 years. Nationalparkforschung in der Schweiz 86. 